


\section{THE UNIVERSITY}

\section{OF ILLINOIS}

\section{LIBRARY \\ 332 \\ B8875 \\ v. 35}

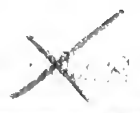


Return this book on or before the Latest Date stampec below.

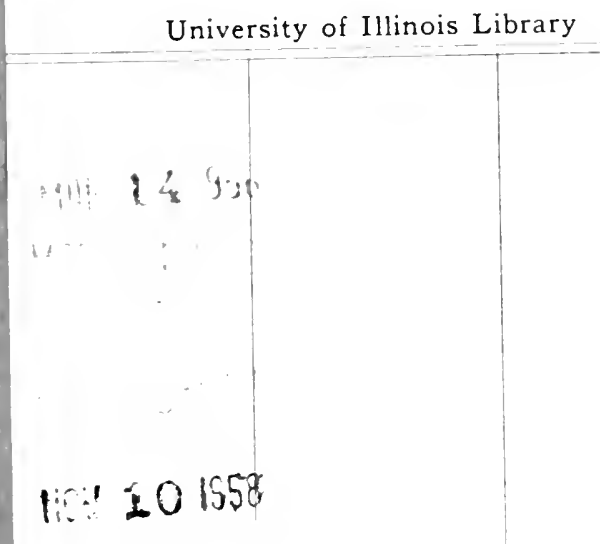




\section{6

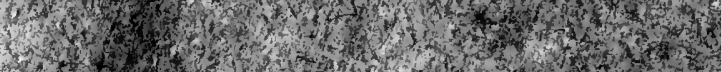

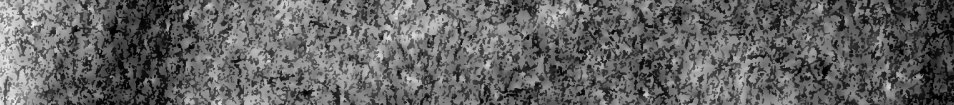

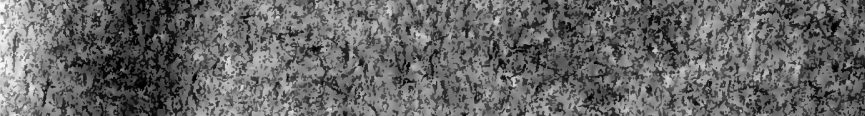

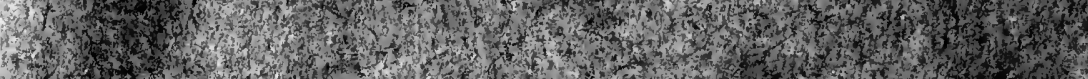

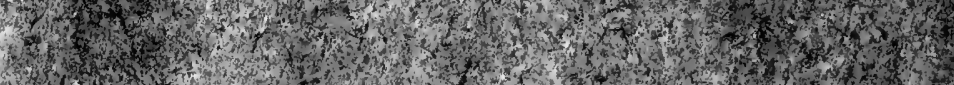

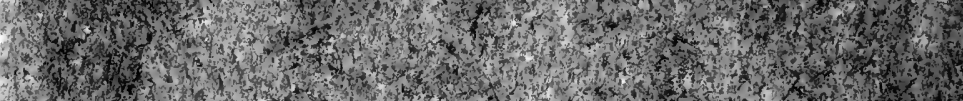

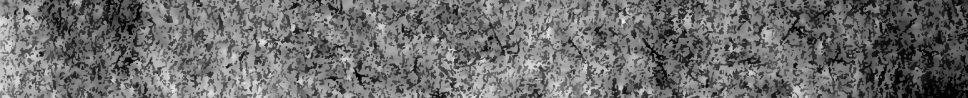
2.

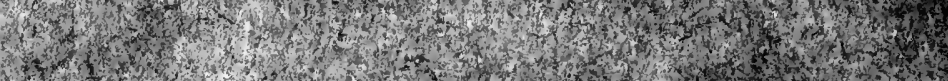

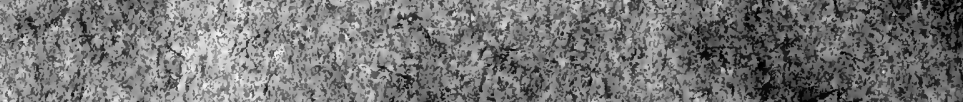

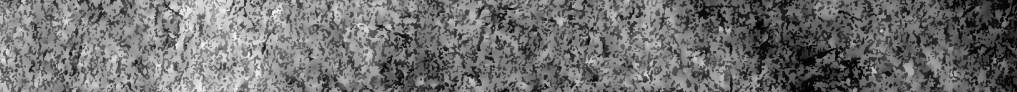

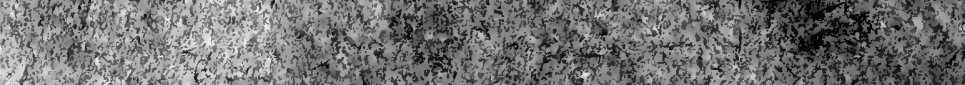

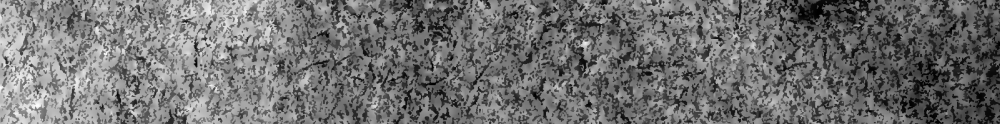

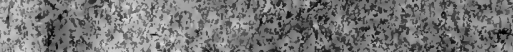

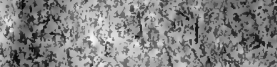

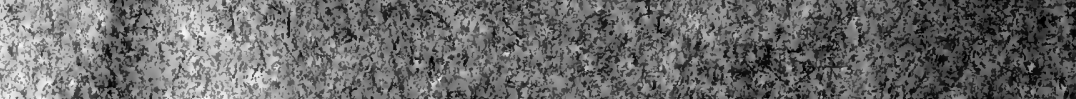

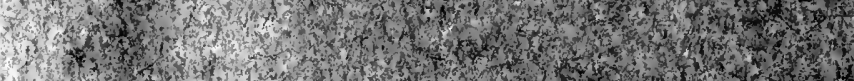
tis

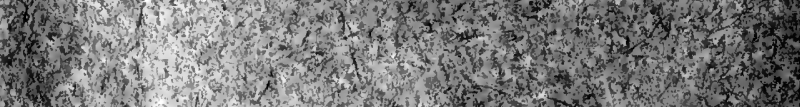

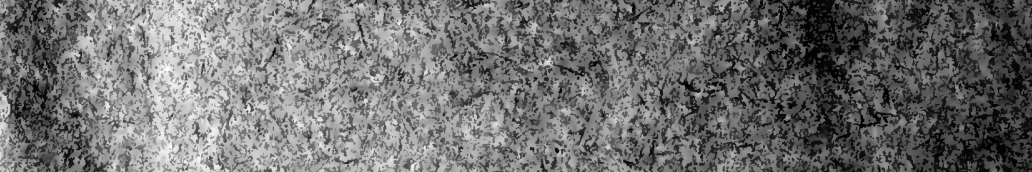

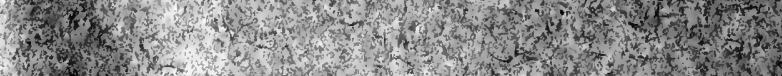

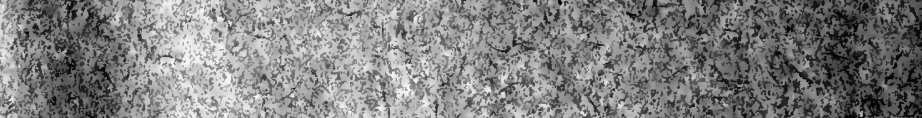
1.5.

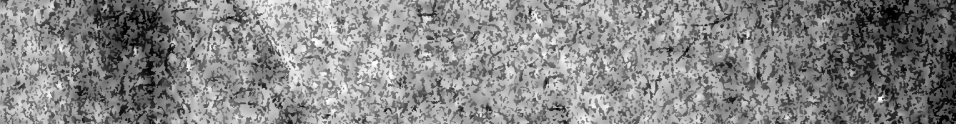

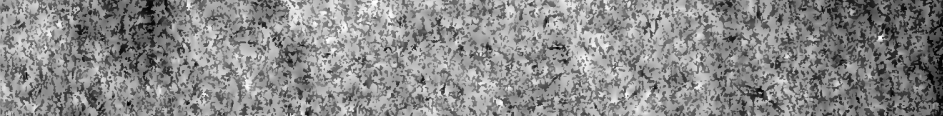
1
1
1 3.

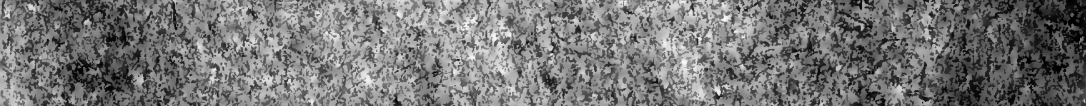

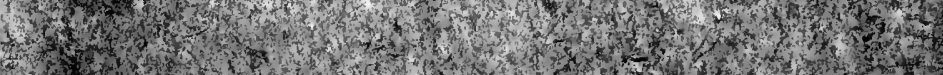

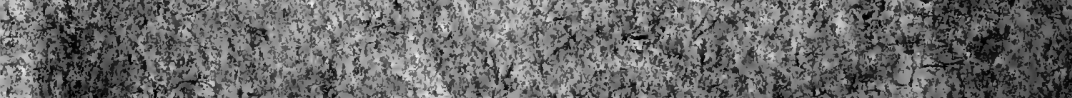
(n)

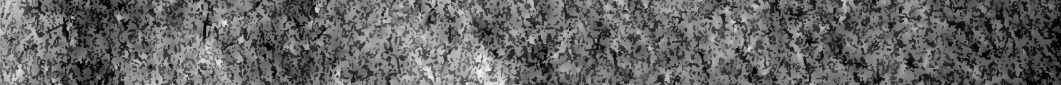

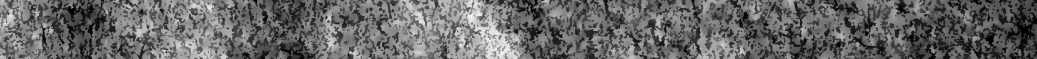




\section{A S E}

For?

\section{PARLIAMENTARY INQUIRY,}

INTO

\section{THE CIRCUMSTANCES}

\section{OF \\ THE P A N I C:}

IN $A$ LETTEL TO

THOMAS GISBORNE, ESQ., M. P.

BY 'I', JOPLIN.

I.ONDON :

J. RIDGEWAY AND SONS, PICCADILIY. 
Lov DON :

Phinted ny ManNixg aro Suthesos, Ivy-Lane, Palemoster Ruw, 
THE great Panic of 1825 was caused by the Bank of England contracting its issues to the extent of three millions and a half, in the short space of six months, and was suddenly arrested by its re-extending them to twice that amount, in as many days. This latter was one of the boldest and most successful measures of a financial character ever adopted, and was the theme of grateful and universal praise, voluntarily tendered to the Bank, but also claimed by the Government of that day for itself. The chief credit of the transaction however, was neither due to the Bank nor the Government, but to the writer of the following pages, from whom it emanated, as by subsequent disclosures he is now enabled to show.

In this pamphlet, evidence is afforded of these particulars with a view to substantiate a claim for a fuller inquiry. It was written two or three years ago, upon notice of a motion by Mr. Gisborne, for a committee to investigate the subject; but the motion has for different reasons been hitherto postponed. It however is presumed that the time has now arrived, or is very fast approaching, when it has a better chance of being attended to. 


\section{THOS. GISBORNE, ESQ., M.P.}

\section{Dear Sir,}

There are but few motions of greater importance than the one you have declared it your intention to make, for a Committee to inquire into the circumstances of the memorable Panic which took place at the close of 1825 . If a plague were to occur, and to baffle every ordinary remedy until the community were on the eve of universal desolation,and if suddenly the contagion should be stopped by the adoption of a bold and novel course of practice -the first duty of the conservators of the public health would be, to ascertain the nature and powers of the salutary specific which had been applied, in order that thereafter it might be safely and effectually resorted to, to check the progress, and prevent the recurrence of similar calamities. Collateral with this, it would be incumbent upon them, as a bare matter of justice, to inquire at whose suggestion the remedy had been adopted, to which the Nation was indebted for its preservation, and officially to notice the fact as creating an individual claim upon the national gratitude.

It is not presuming too much when I say, that something of the same kind ought to have been done, both 
on public and private grounds, after our rapid and unexpected recovery from the Panic. The comntry, however, were so absorbed in joy for having escaped its worst, and secmingly inevitable consequences, that all idea of such a crisis returning, was banished from their minds, and the important principles, to which our salvation was owing, remain to this day far from sufficiently established or understood.

The Committee for which it is your intention to move, will analyze, elucidate, and establish them, so that in future emergencies they may be applied with precision and effect; and parliament it is to be hoped, will not refuse the investigation, if it be only to ensure the safe exereise of that great and irresponsible power with which the Bank has been intrusted. The possibility that it may lead to justice being eventually done to an humble individual like myself, cannot, I an confident, indispose any one against it.

As what may be called the secret history of the Panic may not be universally known, I will beg leave briefly to detail the circumstances of it; and I take the liberty of doing so in a personal address to yourself, with the assurance that the incidental use of your name will give a weight to the narrative, which I cannot expect it to derive from my own.

It is well known that the influx of gold when the exchanges are much in our favour, causes an inconvenient redundancy of capital in the money market of Lendon, and a reflux the reverse ; that is, when gold is imported into London to any considerable extent, capital becomes plentiful amongst bankers and others, and they have more than a usual anomt 
to lend. This reduces the rate of interest, raises the prices of public and other securities, and enables the bankers, bill-brokers and others to accommodate the commercial classes with loans of money for longer periods, and on more favourable terms than usual. On the other hand, when gold comes to be exported to any extent, money becomes scarce, bankers and others have not so much to lend as before, the rate of interest rises, the prices of public securities fall, and the accommodation previously afforded to the commercial classes is suddenly withdrawn, by which great distress and inconvenience are generally occasioned. Neither of these effects are natural. When gold is imported, it is received in payment for our manufactures exported, and adds nothing to the capital of the manufacturer in payment for whose goods it is received. If he receives one hundred pounds in money for one hundred pounds' worth of goods, he is not a richer man than before, with the exception of the profit made upon his goods; and in the aggregate, the chief part of this profit goes to his support. Ninety-nine times out of a hundred also, the money thus received is required for the purposes of his trade. He does not send it up to London from Yorkshire or Manchester or wherever he may reside, to employ it in the funds, or to lend it to the merchants of London. He requires it at home, to replace the goods he has sold, by manufacturing more. On the other hand, when gold is exported, it consists of money paid for foreign produce by the English consumers of it; and if the wine annually consumed by a family in Cheshire, be this year paid for in gold to the foreign producers of it, 
the money for this purpose is neither obtained from the London banker nor the funds, but from their annual incone; and there ought to be no reason whatever, that the money thus taken out of circulation in Cheshire, and sent to Portugal or France, should have any effect in producing a scarcity of capital in London. Such, however, is the case, and it arises from a defect in our system of currency, which renders the administration of the London circulation, by the Directors of the Bank of England, one of peculiar difficulty and embarrassment. I shall not, however, trouble you with the inquiry, how this strange and mischievous anomaly is produced. It is sufficient for my purpose, to state the fact, which though generally incomprehensible, is yet perfectly familiar.

An enormous influx of gold took place from 1819 to 1824 , with the usual consequences, a great superabundance of money, and a very low rate of interest. This gave rise to numerous speculations of a new and adventurous character, as well as a general enlargement of legitimate trade to a great extent on borrowed capital. The Bank might have anticipated that such an overwhelming influx would eventually be followed by a re-action, and that of a very fatal character ; for however inconvenient a superabundance of capital may frequently prove to those who have it to lend, an unexpected scarcity and withdrawal of it from the commercial community, by whom it has been borrowed, is a matter of much more dangerous consequence. Now the Bank entertained an opinion, which was likewise general, that they had the power of almost immediately checking 
the reflux of gold by a contraction of their issues; but as this produces, to a greater or less extent, an immediate suspension of commercial and manufacturing operations, as well as a fall in prices, whenever they use this power, except in a very gradual manner, the result is most mischievous. It ought therefore to be exercised with great foresight, delicacy, and judgment. When, however, the Bank had found, in November, 1824, that a reflux had set in, they did not commence the usual steps they adopt to counteract it; and it was not until the latter end of April 1825, when six millions and a half of their treasure had left them, that they began to contract their issues.

Then, however, they did it with an unsparing hand, and effected in six months, what ought not to have been done, if done at all, in less than two years. A pressure, proportionately severe, was the consequence; which was aggravated by the violent absorption of the circulation, peculiar at such periods to our currency, and threatened the most serious consequences.

From November 1824 to September 1825, they had lost more than ten millions of their treasure, and had little more than three millions left; and as the only means of preventing their ultimately stopping payment themselves, they conceived they must effect a still sharper contraction. As might be expected, therefore, the commercial world presented every appearance of drifting speedily to inevitable destruction.

By the middle of November, the shadow of the approaching storm was upon us. It was yet to burst 
-but the gloom was palpable. The coning confusion, as usual, was first visible in the leaves of the public press; and on the 23d, the Times, one of its most influential organs, took the earliest public cognizance of it. I will trouble you with an extract from that able journal, as it conveys, more forcibly than I. can, the embarrassment of the period, and the popular views concerning it.

"It is said that a degree of difficulty exists in obtaining commercial discounts, which has not been equalled for several years past. That the immediate cause is the extreme caution of the Bank of England, who, seeing a decline in the exchanges, are apprehensive of a fresh exportation of gold, and therefore contract the issues of their bank notes with more timidity than, perhaps, the urgency of the case demands, \&c. That the distress thereby occasioned, would exceed the belief of persons not familiar with the subject: and there is reason for suspecting the attention of Ministers to be, at the present moment, seriously occupied with the aforesaid scarcity of money ; its causes, and, perhaps, its remedies; and that, finally, as the result of the discussion between Ministers and the Bank, the Government must reduce its debt to the Bank; or that the latter establishment will not be able to fulfil the important functions of a discount Bank, so as to carry the trade of the country through the approaching crisis. Such is the substance of our City Bulletin of yesterday, representing, we believe, with much fidelity, the opinions, but with still more exactness conveying, indirectly, the wishes of commercial men, that, by some means or other, the Bank should be, at once, 
enabled and induced to extend its accommodation, in the shape of discount to the public.

"To begin with the latter part of the subject; our own most hearty and earnest prayer to the Bank Directors would be, that no consideration should induce them to extend their discounts, if the condition of the commercial world be truly described in the statements we have just now given."

On the following day the Times intimated the fact that the Governor and Deputy Governor of the Bank, had, at their own request, held a conference with the Chancellor of the Exchequer; and that the principal object of it was, to require of the Ministers, as early as possible, a repayment of part of the advances which they had made on deposits of Exchequer Bills.

The conference with the Chancellor of the Exchequer led to nothing conclusive. The business, the Times informs us, was deferred until the arrival of Lord Liverpool in town on the succeeding Monday; but not the slightest hope was held out that the application of the Bank would be entertained. It was stated to be the opinion of the Chancellor of the Exchequer-and the statement was sanctioned and confirmed by the conduct pursued after Lord Liverpool did arrive-that the evil would work its own cure; and that, in any case, he was not aware that assistance could be given to the Bank by the Government.

In short, all the assistance afforded by the Government to the Bank at this critical period may be said to have been compressed into a figure of speechthey thought that " the evil would work its own cure." That it would be best to let the fire burn itself out! 
The Bank, as subsequently appeared, should have retraced the steps which had led to the evil. They should have re-extended their issues, until the excessive pressure at least was removed; for it was not so much the magnitude, as the suddenness and character of their operations, which had produced it. But so far from doing this, we find that, ten days after, their circulation had actially been contracted from $17,594,301 l$. to $17,497,299 l$.

The immediate cause of these difficulties was not then, if it be at present, generally understood. They were commonly attributed to over-trading and wild speculations; the scarcity of money which existed was imputed to vast amounts supposed to be sunk in visionary undertakings; and the discredit and want of confidence it was presumed would merely extend to those houses who were implicated in them. Hence it was the opinion, that while those who had speculated so rashly would suffer, the sound and sober part of the commercial community would remain uninjured-an opinion so plausible, that we cannot wonder at its being entertained. But what said Mr. Baring afterwards? "A panic had seized the Public. Men would not part with their money on any terms, nor for any security. Persons of undoubted wealth and real capital were seen walking about the streets of London, not knowing whether they should be able to meet their engagements the next day." Nor can we be surprised that a panic seized the public, when the Bank had set the example, by refusing the accommodation necessary to save the country, for the purpose, a justifiable one no doubt, of saving themselves. Can we be surprised 
that men would not part with their money, when the Bank dared not? When the king's ship consults its own safety, is it not to be expected that a convoy of merchantmen will do the same? The panic began in the Bank parlour; and when the garrison shut themselves up in the citadel, it was only natural that the citizens should abandon all idea of mutual assistance in the struggle for individual preservation.

Every day, however, the crisis grew more imminent. On the 29th of November, it was announced in London, that Sir William Elford's bank at Plymouth had been brought to a stop, and that additional embarrassment had been created in the city, from the alarming demand for money which this failure had occasioned. The Country Bankers, of course, began to prepare against a similar fate, and $t_{o}$ call upon the money market of London for supplies. Still not only were the Government and the Directors decidedly opposed to any fresh creation of circulating medium by the Bank, but the Press deprecated it in the strongest terms, and the public themselves coincided with the policy which they espoused. "The main good of the nation," said the Times, " requires that the experiment should work. *** As for relief from the King's Government, the ministers know very well the causes of the evil, and the extent of it, and its natural and appropriate remedies; and we venture to forewarn the men of paper that no such help as they are seeking will be contributed by the State. An inundation of bank notes has aimed at overflowing the real capital of the kingdom. Lord Liverpool, therefore, will think a long time before he does any thing to countenance that original mischief 
under the pretence of curing it." The same sentiments were enforced by another influential organ of public opinion. "That the Bank, at present," said the Morning Chronicle on the 28th, "has only the alternative of limiting its discounts, or becoming insolvent, we can believe;" and on the day following, "the Country Banks can only weather the storm, in any quarter, by the greatest excrtions; and frequent must be the applications for relief, directly and through indirect channels, to the Bank. But the Bank has to choose between its own insolvency, and the insolvency of these imprudent speculations, and as it is quite impossible, in the present state of things, for the Bank, with any regard for its oun safety, to stretch out a firiendly hand to them, the consequences may easily be foreseen."

The mischiefs apprehended from an increase of issues were these-first, that it might drive the exchanges still further against the country, and, by thus continning the drain upon the Bank for gold, finally compel it to stop payment; and secondly, that when any issues that might be made were again withdrawn, as eventually they must be, we should revert to the same situation of difficulty as before. It would be postponing the evil day, not averting it, and create the original mischief, as the Times observed, under the pretence of euring it. With these views it is difficult to conceive how the Directors, in the conscientious discharge of their trust, conld act otherwise than they did. Personally, as merchants, they were deeply interested in adopting any course by which the pressure could have been removed; and when the press arrayed itself on the side of prin- 
ciple-for the press only advocated a line of conduct, as before observed, acknowledged on all hands to be right-it might not be without some misgivings as to the firmness of the Directors in doing their duty under the peculiar circumstances in which they were individually placed. In questioning the policy therefore which the Bank adopted, it is but justice to give the Directors full credit for the integrity by which their conduct was animated. But to resume our narrative.

One Country Bank went after another; the panic reached the London Banks; two or three of the weakest fell at once: and thus matters daily grew worse and worse until Monday morning, the 12th of December, when it was announced that Pole, Thornton, and Co., one of the oldest and largest Banking firms in the metropolis, had stopped payment.

That this would be the case was communicated to the Bankers in Lombard-Street on Saturday night: and some of them called upon the Governor of the Bank, as also upon Ministers, on Sunday, to impress upon them, that if, at that moment, such a House, which was drawn upon by no less than forty-seven Country Banks, were allowed to stop, a run would take place upon every Bank in London, as well as upon every Bank in the country, and a panic would inevitably take place, the consequences of which it would be impossible to foresee. The house, however, was allowed to stop, and a dreadful run immediately took place; a panic seized upon the public, such as had never been witnessed before; everybody was begging for money-money -money-but money was hardly on any condition 
to be had. "It was not the character of the security," observes the Times, "that was considered; but the impossibility of procuring money at all." The next day (Tuesduy) was still worse. It was ushered in by the announcement that Williams, Burgess, and Co., another equally large Banking house, as also two or three more, had been brought to a stand; and the panie beeame universal, and threatened to be irresistible.

It was idle to dream of satisfying the clamorons and voraeious demands of the publie with any thing but money. Nothing but a plentiful supply of Bank issues could meet the exigeney; and this could hardly now be aftorded by the ordinary means of discounting bills. All bills were more or less in diseredit; and, moreover, the amount of money required was such, that the time which would have been oceupied in advancing it upon such securities, would have rendered the relief by discounting, too tardy for the emergency which hat arisen. And this agnin was supposing that the parties in want of the relief had such securities to offer; whereas it was only the City Merchants and Banker's who held such bills as the Bank professes to discount, and money was wanted now by Bankers in every part of the Metropolis, and would quickly be by Bankers in every part of the comntry.

The proper way for the Bank at this conjuncture to give relief, was by bills or loans on government securities. These were the seeurities, in which the Bankers, generally speaking, held the funds, with which they were provided to encounter such an emergeney; and, as they harl become unsaleable, 
their only resource was to procure advances upon them. A hundred thousand pounds, moreover, could be as easily valued in them, and handed over, as a hundred pound bill. In order therefore, to afford the assistance required, and with the promptitude that was called for, the Bank must not only have enlarged its issues, against the judgment of the Government, against the opinion of the public, and against their own conviction; but they must have done so upon a species of securities, inconsistent with the principles upon which their business had always been conducted.

We cannot, therefore, be surprised that the Bank, notwithstanding the events of the Monday, and the growing embarrassment of the Tuesday, resolutely persevered in holding back. On the latter day, many attempts were made to induce them to lend on stock, but without avail. We appeared, therefore, on the eve of an unavoidable convulsion. Another day lost in passive suffering, and the ruin seemed sure and irretrievable. The panic, which had hitherto been confined to London, but of which the elements had already been spread in the country, by the next post, would roll back upon the metropolis, like a torrent swollen from a thousand sources. "The question," says a Bank Director, "had become, not who would fall, but who could stand?" when the Bank suddenly stepped forth, and saved the kingdom from impending desolation, by one of those unexpected movements, by which the fate of a nation is sometimes determined in the chances of war, but seldom in the accidents of its civil condition. 
After having doggedly refused the aceommodation required, up to the moment of closing their doors on Tuesduy afternoon, they opened the next day with a liberality that knew no bounds, and disdained all risks. In the course of Wednesday they began, sudden as a new thought, not only to increase their discounts, but to purchase Exchequer bills, and make adrances upon stock. The day following, they did the same, lending without reserve on any good security, and even, in many instances, taking the security, without wasting much time in examining its validity. All restriction upon their issues, was now out of the question. The only consideration was, how they could issue fast enough. The sovereigns they gave out by weight, to save the interruption of counting, and handed over their notes as fast as they could be told; until, in four days, they had neither a sovereign nor a note to go on with. On Saturday night they could not give any kind of change for fifteen of their own thousand pound notes.

The rapidity with which they cnlarged their issues, when they once set about it, has no parallel in their history. From November the 19th, to December the 3d, their issues remained nearly at a stand; from December the $3 \mathrm{~d}$, to December the 10 th, they only varied from $17,477,290 \mathrm{l}$. to $18,037,960 l$.; but on Saturday, December the 17th, they amounted to $23,942,810 l$, and on the 24 th of that month, were swelled to $25,611,800$. Including their issues of gold, they must have distributed nearly ten additional millions of currency in the short space of eleven days, seven of which would be issued in the 
first four. The following is a weekly account of their issues of paper, from the first Saturday in September to the last in December,

$£$.

1825.-Saturday, September 3 . . . 19,028,060

Ditto October 1 . . . 18,536,550

Ditto November 5 . . . 18,497,400

Ditto $\quad 12$. . . 18,031,860

Ditto $\quad 19$. . . 17,594,280

Ditto 26 . . . 17,464,880

Ditto December 3 . . . 17,477,290

Ditto $\quad 10$. . . 18,037,960

Ditto $\quad 17$. . . 23,942,810

Ditto 24. . 25,611,800

Ditto $\quad 31$. . 25,709,410

A measure so sudden and unexpected, so opposed to the general practice of the Bank, and carried to such an extreme in the teeth of their own prejudices and of public opinion, it is not probable that they would have undertaken on their own single responsibility. The Times, on the subsequent Friday (the 16th), adverted to a rumour of the Government having recommended the Bank to purchase a few Exchequer bills; and seemed to think such an act of interference too curious to be true. But it was true; and the only curious part of the story is, that up to the Tuesday afternoon, their recommendation went no further. There was much assertion and contradiction at the time, as to whether and when the Government interposed its advice. Mr. Huskisson declared, that the Bank had acted throughout with the countenance and concurrence of the Government, which decides the fact that the Government sanctioned the sudden change which the Bank adopted on the Wednesday. 
At the same time it is demonstrable from subsequent disclosures, that this change was not meditated, either by the Government or the Bank, until after the hours of business on the Tuesday. In the Appendix to the Report of the Bank Charter Committee, we find the following conclusive minute.

"At a Court of the Directors at the Bank, Tuesday December 13th, 1825, the Governor laid before the Court the following note from the First Lord of the Treasury and the Chancellor of the Exchequer, viz.

"In order to relieve the present distress in the money market, the First Lord of the Treasury and the Chancellor of the Exchequer, are prepared to give immediate directions for the purchase of $300,000 l$. Exchequer Bills, in addition to the 200,000l. which they understand the Bank directed to be purchased yesterday.

"If it should be thought, however, more advisable that the whole $500,000 \mathrm{l}$. should be purchased by the Bank on their own account, the First Lord of the Treasury and the Chancellor of the Exchequer, will be prepared, if the Bank should require it, immediately to redeem the same.

$$
\text { Signed, } \quad\left\{\begin{array}{l}
\text { Liverpool. } \\
\text { Frederick John Robinson. }
\end{array}\right.
$$

Treasury Chambers, Dec. 13th, 1825.'

"Resolved,

"That the Goremor be authorised to order the purchase of Exchequer Bills to the amount of 500,000l. upon the conditions specified therein."

Without explanation, which the transaction does not bear upon the face of it, it is difficult to con- 
ceive how the purchase of $500,000 l$. worth of Exchequer Bills by 'the Government, could afford relief to the money market, even to that limited extent; for the question naturally arises, where did the Government get the money? They do not keep bank notes in the Exchequer. The place of deposit for the money of Government is the Bank of England. This purchase of Exchequer Bills by the Government must therefore have been made by a cheque upon the Bank, the providing for the payment of which must have limited the advances of the Bank to the public in some other way, to an equal extent; so that nothing would be gained. Assuming it, however, to have afforded the amount of relief proposed :

It is clear from this document, that a purchase of 500,000l. of Exchequer Bills was on Tuesday the utmost relief contemplated, from which it is evident that the measures pursued on Wednesday had not then entered into the views of the Government or the Bank. Nor were the public at all prepared for the change. To the last moment it was deprecated by the press; though, no sooner was the experiment adopted, than they gave it their approbation and support. The question now is, what produced it?-That it neither originated with the Bank, nor with the Government, I think is obvious; for even after adopting it, they were not aware of the amazing effect it was calculated to work. At the very moment they were venturing upon it (on the Wednesday), the Bank applied to the Government for a restriction; the Government on the other hand, advised the Bank to stop on its own responsi- 
bility, and to give notice of resmming payment in February ; and "the Bank," says the Deputy Governor in his evidence, "not being clear that it could do so," refused to implicate itself in any such pledge. When people pursuc measures of their own, they know what they are about, and have made a calculation at least of the result to be expected. On the contrary, when they adopt the systen of another, the operation and tendency of which they do not elearly comprehend, they can never wait coolly and confidently for the result. The Bank and the Government were manifestly in this latter situation. Where, then, are we to look for the source of the successful policy which they followed? It must either have been an inspiration from above, or a suggestion of earthly origin; and as there is no necessity to suppose a miracle, where a natural cause, adequate to the effect, is at hand, I venture to presume that it may be accounted for as follows:-

The Directors, as I have before remarked, apprehended that an increase of their issues would turu the exehanges against us, and lead to a demand for gold, which might ultimately bring the Bank to a stoppage. The same opinion was entertained by the public generally. It was not perceived that a demand for money in ordinary times, and a demand for it in periods of panic, are dirmetrically different. The one demand is for money to be put into circulation; the other, for money to be taken out of it. A person, who wishes to have the conmand of a liundred pounds, places it with his banker. When the banker falls into discredit, he takes it from him, not to spend, but to kecp in idle security at home, until he sees whether 
the banker will stand. Money, thus required, is not required for circulation, but to be hoarded; and the moment that confidence is restored, it will be returned to the banker again. This distinction did not strike the Government, the Bank, or the public; and therefore it was not observed, that a demand for money, arising from panic, might be supplied with safety; that the money advanced would not enter into consumptive circulation, so as to effect the exchanges, by elevating prices, but would spontaneously return on the recovery of credit.

Simple as this view of the matter may appear now, it struck, as before remarked, no one else at the time. Convinced, however, of its correctness, and that it was in my power, if I could command attention, to redeem the country from a capital and mischievous error, I sent the following to the Courier (the official organ of the government), on the Tuesday morning, and the editor made it his leading article for that day.

“Tuesday Evening, December 13th.

"There never was, perhaps, less real cause for commercial embarrassment than at the present moment; and no doubt can possibly be entertained that the actual distress in the money market arises in part from obstructed circulation, produced by want of confidence, and in part from the great supplies of sovereigns and Bank of England notes, which have been sent down to the Country Banks, in all parts of the kingdom, amounting, probably, in the aggregate, to many millions. There are between five and six 
hundred country bankers in England, exclusively of Scotland; and there is little donbt that every one of them has thought it necessary to increase his stock of gold and Bank of England notes to a greater or less extent, and the whole of this supply has been taken out of the money market of London.

"The best possible proof that the present difficulties are the mere result of want of confidence, is the finet, that there are no such difficulties where this want of confidence does not exist. By our accounts from Scotland, we find that there, all is tranquil. Money laas been more in demand of late, bit this appears to be rather a beneficial result than otherwise. People are making more money in their respective trades, and are willing to give a better interest for it. Bankers, consequently, are not only enabled to charge a higher interest for the money they lend, but also to give a higher interest for money deposited with them, which they have lately commeneed doing. The same is taking place not only in Ireland, but in those parts of England where there is no want of confidence. As soon, therefore, as confidence is restored, the distress will be at an end. This, however, in the mean time, may be very much relieved by the Bank of England, who, with perfect safety, might issue notes to the extent of those either withdrawn from circulation by individuals, or sent into the country. In so doing, they would not add to the circulation, but only supply a vacuum in it; and the moment confidence returns, they may withdraw the whole amount of notes thus issued to meet the present emergency. 
"In the state of the money market, the Directors have a very easy test by which to regulate their issues. So long as the pressure is unnatural (of which they will be able to form a tolerable judgment) the demand must be unnatural, and may be supplied without any increase to the quantity of money, which would otherwise have been in actual circulation. On the other hand, when confidence is restored, the Directors will perceive, by the depreciated value of money in the market, the period when the money hoarded and supplied to the Country Bankers is beginning to find its way back into the circulation of London, and this, of course, will be the proper time for withdrawing their surplus issues.

"We have reason to believe that this policy is actually pursued by the Bank to a considerable extent. They are, no doubt, increasing their issues.* But considering the pressure in the money market, we conceive they might go considerably further with perfect safety. The Bank, indeed, is, in a great measure, bound to administer the relief necessary upon such occasions. It is certainly a defect in our present system of currency, that it is liable to be contracted by a touch, or frightened, as it were, out of circulation by the mere breath of opinion. But this, perhaps, is in some measure caused by the charter of the Bank itself; and it is bound to supply the deficiencies caused by such alarms, when they occur.

"We believe also, the Bank need not fear that

* They had enlarged their discounts by increased issues of gold, but the probability is, that they luad not increased their issues of paper. 
any issue of their notes could turn the exchanges against the comntry, until long after confidence was restored, even if those issues were carried to a comparative excess. Adam Smith has somewhere likened an excess of circulation to too much water put in a vessel, which, consequently, runs over ; and we perceive that many of our contemporaries imagine that the Bank have the power of turning the exchanges in our favour, or against us, by merely putting their notes into circulation, and taking them out again. The issues of the Bank, however, conld only affect the exchanges, through the medium of an elevation or depression of prices increasing or diminishing the amount of our exports or imports, which must be an operation of many months; and we feel some degree of confidence, therefore, that the Bank, for a temporary purpose, might increase its issues with less rescrve than has been sometimes supposed necessary."

The next (Wednesday) morning, the Bank instantly and vigorously adopted the policy recommended and explained in that article; and having once induced them to commence a bold but judicious operation, the great matter was, to inspire them with courage to proceed with it. The finessing between the Bank and the Grovernment on the Wednesdaytheir higgling for a suspension, but diplomatising to throw the blame upon cach other-shews that they wanted no little fortifying in the resolution they had taken; and I therefore continued to address myself daily to the same subject in the same manner, until every danger and doubt had subsided. It is only, 
however, to the two following articles that I shall more particularly call your attention, for the sake of illustrating the principles to be investigated. The first was intended more effectually to dissipate the apprehension of the Bank, that the exchanges would be affected by the expansion of their issues; and the next to enforce the prudence of a prompt and sufficient supply, by proving the facility with which the surplus issues would be withdrawn when the crisis was over.

\section{The Exchanges would not be effected by an enlargement of Issues.}

“Wednesday Evening, December 14th.

"The resolution of the Bank to increase their rate of interest to five per cent. is perfectly justifiable at the present moment; but whether the real value of money will justify the change, after confidence is restored, they will discover by experience. No objection, however, can possibly be made to the change, under existing circumstances, if the Bank will but supply the dreadful vacuum, which want of confidence has caused, and continues to cause, in the circulation.

"That the Directors have every disposition to do this, we are well assured; and the question, we believe, with them is, how far they can do it with safety. The danger they naturally apprehend is, that, by an excess of issues, they may turn the exchanges against the country, and create a demand for gold which they cannot supply.

"If the present demand for money were a natural 
one, we have no doubt that, in the course of twelve months, an increase of issues might have that effect. The money issued would be employed in increasing the stocks of the merchant, and the employment of the manufacturer; by which means the general consumption would be increased, and a corresponding elevation of prices would follow. This would increase the foreign demand for our manufactures, and of course diminish our exports, on the one hand; while, on the other, an additional consumption would take place in foreign commodities, as well as in our own, and increase our imports. Thus our exports being: diminished, and our imports being increased, gold would be demanded of the Bank, with which to pay the difference. It is quite idle to suppose that the issues of the Bank can affect the exchanges, or the exportation and importation of gold, except by a process similar to this. Money comes into the country, or goes out of it, in actual payment for commodities which have been previously exported or imported; and before the exchanges can be effected, an alteration in our exports or imports must take place.

"The simple question, therefore, for the Bank Directors to ask themselves, is this: Does the present excessive scarcity of money arise from a demand for capital, to be immediately employed in commercial, manufacturing, or other speculations, by which consumption will be generated and increased? If it do not arise from this cause, the demand may be supplied by an increase of issues, on the part of the Bank, with perfect security; and we may safely say, never was the commercial and manufacturing world more inno- 
cent of any intention to increasc their operations than at this moment.

"The present scarcity of money is the mere result of alarm and want of confidence; and as the demand has been a sudden one, so ought the supply to be. A judicious and adequate relief afforded by the Bank, at the present moment, would, we are persuaded, restore confidence in a few weeks.

"We do not, by any means, wish to be understood as proposing that the Bank should make advances to bankers, without adequate security. But if a banking house be pressed, or has a run upon it, and wishes for assistance, we do think, provided the security offered be sufficient, that the description of such security ought not to be considered too scrupulously. By meeting the present difficulties in a manner at once judicious and decisive, we are persuaded, that it is in the power of the Bank to end them with perfect safety to itself; and we trust that the Directors will not, from a misplaced caution, which, in point of fact, would, at this moment, be the greatest rashness, allow the present temporary but alarming pressure for money, and want of confidence to be increased."

Prompt Supply of Notes required, which Supply may be afterwards withdrawn without danger.

\section{“Thursday Evening, December 15.}

"A Meeting took place at the Mansion-House yesterday, to consider the present alarming state of public credit. Of the proceedings at this Meeting we gave some account in a second and third edition of our paper of yesterday; and for more detailed par- 
ticulars, we refer our readers to our columns of this day. At this meeting it was stated that Sir P. Pole and Co. have a surplus of one hundred and seventy thonsand pounds, after the payment of all claims upon them, besides the large landed property of Sir Peter Pole, and about one hundred thousand pounds the private property of the other partners of the House; and that Williams and Burgess have property sufficient to pay forty shillings in the pound. We have little doubt, also, that the other Houses that have since stopped payment, are equally competent to pay all claims upon them.

"When we thus perceive the perfect solvency of the two Houses above-mentioned, we cannot but consider it a most unfortmate circumstance, that they were allowed to come to a stand, at such a time, for want of proper assistance. It might, with certainty, have been anticipated, that the stoppage of two such houses would produce all the consequences that lave ensued. There are times when rules and precedents cannot be broken; others, when they cannot be adhered to with safety; and it is extremely probable, that if the Bank had done on Saturday, what they have done both yesterday and to-day, (Wednesday and Thursday), namely, advanced upon other securities than bills, these houses would not have stopped payment, and confidence by this time, instead of being almost destroyed, would have been nearly restored.

"Neither the amount of the advances which the Bank may have made, nor the securities they may have accepted, will now, we understand, meet the exigency, and further extension must take place in 
both these respects. It is a mere waste of time and words to talk of restoring confidence at the present moment with any thing but money. The case is not one to be met by palliatives. If a sufficient supply of money be not afforded by the Bank, the only source whence it can be supplied, we should fear to trace what, in our opinion must be the consequences.

"When we press this upon the consideration of the Directors, we do it, with a perfect conviction, that they may afford the relief required with safety. So soon as confidence is restored, we are persuaded that nearly the whole of the extra advances made by the Bank, will be returned upon it without any effort of its own.

" The individuals who now draw their money from their bankers and keep it at home, will replace it again in their hands, and the Country Bankers will reduce their stocks of Bank of England notes and gold to their original amount, by returning to their agents, in London, the extra supplies which they have lately received. By this means the London Bankers will be overstocked with money; be enabled to pay off any debts they may have contracted with the Bank of England; and, instead of applying to the Bank for discounts, they will on the contrary discount freely themselves. When this is the case, the Bank Directors are well aware that their issues will contract without any effort on their part.

"We do not mean, however, to say that the Bank need trust to their surplus issues-put forth to meet the present exigency, being thus returned upon them ; though, we are of opinion, if they continue to charge five per cent. interest, that this will be the case. 
We merely advert to this, to shew the ease with which they may, at any rate, be withdrawn at the proper period.

"If the Bank recal their additional issues when the alarm is over, and before matters have been so long settled as to give time for their being applied in commercial, manufacturing, or other speculations, they may be increased without any inconvenience. It is a perfectly sound operation to make a temporary addition to the circulation, equal to the emergency, at such a period as the present, to be withdrawn again, without hesitation, when the crisis is over. Every reflecting person will agree with us on this point; but even those who do not, and who contend that such a temporary advance is an evil, must admit, that it is a much less evil than that which it would remedy. It, however, would not be an evil. When want of confidence prevails, twice the amount $o$. currency becomes necessary to conduct the same operations, at the same scale of prices as before, and nothing can be more legitimate, than to supply such extra demand for currency while it lasts."

As before stated, other articles were written to the same effect, but it is unnecessary to quote them. Now, considering all the circumstances of the caseconsidering what the Bank did, and how, and when they did it-considering that up to the close of business on the Tuesday, up to the very moment of the publication of the first of these articles, the Bank and the Government had no idea of any further relief than the purchase of half a million of Exchequer Bills-that their first and immediate step after its publication, was to follow implicitly the course it 
suggested, though opposed to the policy to which they were in some degree pledged by so long persisting in it, though contrary to all the ordinary rules of their business, and repugnant to the hitherto expressed opinions of the Ministers of their own body, and of the public ; considering, moreover, that their doubts and fears did not subside, even after they had committed themselves to the experiment; until the second article, which was ealculated to allay their apprehensions from the exchanges, had made. its appearance on Wednesday:-considering these remarkable coincidences and consequences, and that, amidst the confusion of all parties urging the Bank on to the gulph of universal bankruptcy, mine was the only voice' (if I may use the expression) to call upon it to retrace its steps; no reasonable man will deny but that there is something more than presuniptive evidence, for attributing to these articles the adoption and prosecution of the measure, by which the country was saved from commercial, and perhaps from civil desolation.

There are some people so peculiarly fortunate, as to achieve success by means which would be the ruin of others. In this case the Bank, the original cause of all the mischief which had ensued, as matters turned out reaped nothing but praise for what they had done. Ministers took the Directors by the hand in mutual congratulation; Parliament applauded them; and the country was grateful beyond expression. No event in the history of the Bank, ever won for its Directors so large a meed of public favour, or raised their reputation so high in public estimation as managers of the eurrency. Panegyrie was un- 
sparingly lavished upon them from all quarters. Nor diel it appear to me to argue badly for the principles and feelings of minister's, that they set the example in these expressions of gratitude, and were disposed rather to overrate than undervalue the merit of the Bank.

I could not then publicly avow myself the author of those articles. In sending articles to newspapers -which has always on my part been done gratuitously-secresy as regards the public, is one of the conditions implied. In the present instance this was more especially necessary, as the articles were supposed to have been furnished by the Government itself to its usual organ of communication; an impression, which no government paper would wish to be impaired. But from the liberal and liandsome manner in which the Ministers had behaved to the Bank, it was not unreasonable to imagine that if informed who was the author of these articles, they could not fail, though of course in a more private manner, to notice in some way the service he had rendered: for no one can desire so undefined a body as the public to receive important benefits at his hands without some kind of acknowledgment. I lowever thought it advisable to feel my way cautiously; and I induced Sir Thomas Lethbridge, to mention to the Chanecllor of the Exchequer, in the first place, that the articles in question were mine, and hear what he had to say upon the subject. In doing this, Sir Thomas perceived, from his expression and manner, that the intelligence was not without interest; but his acknowledgment extended no further than that he was not before aware who had written them. If there was 
nothing to encourage me in this, there was nothing the reverse; and I should have taken other steps, had not a fact come to my knowledge which deterred me.

On sending Mr. Mudford, (the editor of the Courier) a short article for the Monday or Tuesday, after the week of the Panic, I mentioned to him in a note, not intended for publication and marked private, the fact, that the Bank of England had been so close run on the preceding Saturday night, as to be unable to change either in paper or gold fifteen of its own thousand pound notes. The Panic was over in London, but was still raging in the country. The Country Banks were pressing as much as ever upon the Bank of England for supplies; and as the Mint, working day and night, could not coin more than 100,000 sovereigns in twenty-four hours, it was possible that the Bank might not be able to meet all the demands upon it with the promptitude required. Such being the case, it was perhaps not unwise to prepare the people in the country for some tardiness or short stoppage on the part of the Bank, by a notice, given in an unconsequential manner, of its being so closely pressed for time; and Mr. Mudford ventured to insert the fact I had communicated to him. The Panic being over in London, no harm could well arise from this; and, if it did no other good, it might have furnished such of the Country Bankers, who were too closely pressed, with an excuse for not being better supplied with change. I think he acted with judgment, and certainly with the best intentions, in making the fact known to the public. Lord Liverpool, however, thought other- 
wise. He saw danger in it, as in everything else; and had the fact contradicted. No harm resulted from the statement, and it was well that none resulted from the denial. Nerertheless he was pleased, like most people who are frightened, to fall into a passion with the unfortunate editor, and went so far as to meditate lis ruin, by insisting on his dismissal. Nor was it a mere expression of displeasure, conveyed to the proprietors, which might have been intended as a warning for greater discretion in future. He actually went so far as to provide another editor for the paper himself; and would certainly have effected his purpose, had it not been for the inflexible remonstrances of $\mathrm{Mr}$. Canning. This conduct to say the least of it was very extraordinary. A member of his own government, and a great authority in such matters, Mr. Huskisson, spoke of the deliverance which had been effected in the following: terms: "of this Panic, no man could tell what might have been the consequences, if the Bank had not stepped in, and, by their timely and liberal interference saved the country from destruction." He also remarked, "if the difficulties which existed in the money market a short time since, had continued for only eight and forty hours longer, he believed the effect would have bcen to put a stop to all dealings between man and man, except by means of barter. It had very truly been observed, that the Bank, by their prompt and efficacious assistance, had put an end to the Panic, and averted the ruin which threatened all the Banking Establishments in London, and, through them, the Banking Establishments and monied men all over the country. The conduct of 
the Bank had been most praiseworthy, and had, in a great degree, saved the community from a general convulsion. He would take upon himself to say, that the Bank, throughout their prompt and efficacious, and public spirited conduct, had had the countenance, advice, and particular recommendation of the First Lord of the Treasury, and his Right Honorable Friend the Chancellor of the Exchequer to assist them.*"

Hansard's Debates, vol. 14, p.

Now when the service rendered through the medium of the Courier in bringing about this great deliverance is considered, - a service which Lord Liverpool was unable to perform himself, although not unwilling to share the credit of it,-his proceeding against the editor appears almost incredible. It was, however, such as I have stated it to be, and I of course declined taking any further steps respecting myself in the matter. But as the present time is more favourable; as no necessity for secresy with respect to these articles any longer exists; as there is no statute of limitation against the reward of public services, and as I have obtained the requisite evidence, I trust it will not be thought improper to call public attention to the subject.

If the suggestion had been merely accidental, the public were equally benefited by it, and ought not to undervalue it on that account. But such views are rarely accidental : for though they may appear simple, and produced without effort, the principles which lead to them are generally the result of much previous labour and reflection. This was my case.

* Lord Liverpool and Mr. Robinson, now Lord Ripon. 
I was then publicly engaged - both theoretically and practically-in the subject of which this recommendation formed a branch. Now whatever may be thought of the law of patents in other respects, no objection can be urged against the rationale of insuring to every man some of the fruits of his own labour. This is a debt which Society owes to every one of its members; and, where from the peculiarity of the case, it cannot be discharged in the ordinary manner, it is the duty, and usually the practice, of the legislature to step forward, and bestow that reward upon the discoverer, which he has no means of securing to himself. In mechanical inventions men find their reward in the profits accruing from them: but there are discoveries from which no particular benefit can result to the individual, though of immense advantage to the public at large. In such cases the public, or rather those who administer the public affairs, are justly bound to make some acknowledgment; and, if the facts which I have stated can neither be confuted nor explained away, I think that it will not be denied that I stand in some such relation to the country, for having chalked out a path, by which it eseaped the most tremendous convulsion which ever threatened its conmercial prosperity.

Should however, the Committee discover that justice remains to be done to me, or to anybody else, this will be only one of the minor incidents of the investigation. The grand result to be obtained is, a sure and satisfactory knowledge of the principles, upon which the Bank, in such situations should act in regulating their issues-a knoviledge which it may be doubted whether the Bank Directors have yet fully 
attained. This appears to me to have been rendered sufficiently obvious in the evidence given by the $\mathrm{Di}$ rectors, before the Bank Charter Committee of 1832. There is much curious and important matter in that evidence, but the Committee made no report; and seeing that anything but the right conclusions were likely to be drawn from it, I ventured to take the liberty of making a few observations upon it myself,* from which I beg leave with reference to the point in question, to make an extract or two.

"We must observe in the first place, that one of the advantages which may be adduced as a set-off against the many evils of a paper currency such as ours, is the facility with which it may be expanded upon extraordinary occasions when wanted. A striking example of this was exhibited during the great panic of 1825. The usual demand for money then experienced, was not for the purpose of additional circulation. It was to supply a vacuum in the circulation, which the fears of the timid for the safety of the Banks had caused. People were led to withdraw their deposits, and to demand payment of the country Bank notes in gold, or the notes of the Bank of England, not for circulation, but to lock the money up in their strong boxes at home, until their confidence in the Banks they dealt with had revived. In meeting this demand by an increase of issues, the Bank did not add to the practical circulation, they only supplied the want of it which the panic had

* I did this by way of preface or introduction to a digest of the evidence which I took upon me the labour of preparing for Messrs. Ridgeway and Sons. I have not, and never had any personal interest in the publication. I may, therefore, perhaps, be allowed to recommend it as a useful book of reference: the materials in the original report though exceedingly valuable, being presented in so confused a mass as to render them nearly useless. 
caused: and they were enabled to increase their issues to the extent of eight or ten millions on securities, not only with the greatest advantage at the time, but without any subsequent incon venience being experienced on the withdrawal of this large sum.

"The value of such events in the hands of those who endearour to turn the experience of the past to the benefit of the future, is not of course confined to the immediate practical good experienced. It could not but be obvious, that what required eight or ten millions in December, might perhaps have been prevented by one or two millions at an earlier period. But at all events it was clear, that a demand for money not wanted for circulation might be supplied over and above the regular amount of issues, and withdrawn at the proper period without any inconvenience, and consequently that such demands in future ought to be met by a prompt and adequate supply of the amount of additional circulation which might be called for.

"Now the demand experienced by the Bank, in May 1832, was clearly of this description. During the ministerial interregum of that month, when the King sent to the Duke of Wellington to form a Tory administration, the public, in order to embarrass the embryo government, and defeat the attempt to form it, made a run upon the Bank of England for gold to the amount of two millions. This demand was for money to be withdrawn from circulation; and the Directors were aware that the circulation was proportionately contracted. Mr. Ward observes, (Question 22073) - There has been a diminution of nearly two millions sterling in consequence, and I 
do not hesitate to say, the public is suffering very considerable inconvenience from the circumstance; but I do not know how to alter it.' And they did not alter it. But their experience had, or ought to have taught them, that the proper mode of altering it was to re-issue the notes on securities until the gold returned, and this it was obviously their duty to do.

"Politically speaking, the course they pursued was in the minds of the parties by whom the gold was demanded, most desirable. It was giving the wished for effect to the objects they had in view, which were evidently to cause embarrassment and alarm.

"But the Bank have nothing to do with politics. They have a discretionary power given them, to be exercised not for political objects, but for the protection of the circulation against derangement; and they ought, in order to discourage such attempts in future, to have taught the public, by re-issuing their notes as fast as they were brought in, that no sinister effect whatever would be produced on the circulation by any such means. If the public were thoroughly satisfied that a political panic would do no harm to any, but to the parties who were the cause of it, such measures would never be resorted to for political purposes, and such panics would never be repeated.

"The Bank, however, took a different view of their duty, and imagined they were acting in strict accordance with it, in contracting their issues; for they seem to take credit to themselves for the line of conduct they adopted. Mr. Ward's explanation of the transaction is curious, and is as follows :-

"(22073). "Do vou hold the opinion to be a cor- 
rect one, that the Bank should conduct itself in its issues, with reference to the state of foreign exchanges and the bullion market?-Aus. Certainly: I do not think there is one person in the Bank of England that denies it, or is disposed to act in opposition to it; but over and over again I have been responsible myself for violating it, when some extraordinary case has arisen, and I think I can hardly state a more extraordinary case than what has arisen at the present moment. Since the month of March a most enormous amount of gold has found its way into the country, probably as great as ever found its way in a corresponding period of time. My reasoning would be, that the public ought to have the benefit of that, by an increased circulation. That is the effect that would have been produced, if nothing but the king's gold currency existed. At the present moment the Bank of England notes are at a lower point than they hare been for some years; they are at $16,600,000 l$. Then a person would tell me, that in pursuing that course, I violate the very principle I contend for: and the fact is so: but I cannot help it, for the solution of the question comes thus; - when his Majesty thought proper to send for the Duke of Wellington, portious of the people chose to come to the Bank, and to take coin for their notes. There has been a diminution of nearly $2,000,000 l$. sterling in consequence of that, and I do not hesitate to say the public is suffering very considerable inconvenience from the circumstance; but I do not know how to alter it. My business was, that the public should have a supply when they demanded it, and they had a right to demand it.' 
"The question, however, is not whether the public should have the gold, but whether the Bank, as conservators of the currency, ought to have allowed it to be deranged by such a cause, more especially as they could have prevented it without any practical inconvenience. But the curious part of the affair is the admission of Mr. Ward, that they violated their own principles on that occasion. Their stated principle, as we have seen, is, that their issues, and consequently the issues of the whole country, shall be regulated by the foreign exchanges. But their practical rule of business is that the state of exchanges shall be indicated by the actual demand for gold, which they term the action of the public. If a person come and demand gold, they infer as a general rule, and as a general rule the inference is correct, that if he does not want it for small change, he wants it for exportation, and vice versâ.

"But here it was known that the gold called for was not wanted for exportation, and that the currency of the whole country, as well as the money market, would be deranged by the unusual demand. Yet they felt themselves compelled to adhere to their rule, and did so, though they at the same time violated their principles.

"But, as Mr. Ward says, they have over and over violated their principles in the same way; and though it is not specifically stated, yet we are left to infer that in 1828, when Mr. O'Connell caused a panic in Ireland, which produced, it seems, a demand upon the Bank for 1,000,000l. of gold, he deranged the English circulation as well as the Irish, and produced a certain degree of embarrassment 
here as well as in Ireland; and that the Emperor of Russia, when he made war upon the Turks, and obtained a million of money from this country to assist him in his operations (which he did at a period when our currency was deficient, and the exchanges in our favour, 2134), did, in fact, make every Englishman, as well as the Turks, suffer from the effects of his campaign.

"This is probable, though not distinctly stated. But if there could be any doubt upon the subject, it is removed by Mr. Palmer.

" 'If the drain,' Mr. Palmer is asked (2416), ' of bullion from abroad proceeded, in your opinion, decidedly from political discredit there, not indicated by the exchange being below par, and not to be traced to an over issue of paper in this country, would you contract the circulation under those circumstances? Answer. The public would contract the circulation, if bullion were required for exportation, by returning the notes of the Bank.'

"That is to say, they would not break their rule, however obvious it might be that the demand for gold was a foreign one, arising out of events abroad which had no commexion with our currency."-Digest of Evidence before the Bank Charter Committee.

It is, in short, clear, not only from the above observations, but generally from their evidence before the Committee, that the Directors have not deduced those principles from the Panic, which its history ought to have established, and by which they ought to govern themselves under similar circumstances; and that, consequently, unless the subject receive some such investigation as proposed, no great re- 
liance can be placed upon their turning the experience it has afforded to the proper account at the proper time.

But were it otherwise, when we consider the changeable nature of the Bank Direction, and the important trust imposed in it, it is not right that a proceeding of such consequence should be left in that state of mysterious obscurity in which it is now involved. Every new Director, at least, will be in the dark, and no one should be allowed to take upon himself an office of such vital interest to the nation, without every opportunity being afforded him of acquiring the general principles on which its administration should be based. In every view, therefore, a proper investigation of the subject is desirable, and I am willing to hope will not be denied.

I am, Dear Sir,

Your most obedient Servant, Thomas Joplin. 


\section{POSTSCRIPT.}

Tire object of the foregoing jamphlet, as will have been observed, is to exhibit the grounds on which the House of Commons ought to grant a committee, to investigate into the history and circumstances of the panic of 1825 : which grounds may be thus recapitulated.

First.-What such an inquiry is demanded, by justice and fair dealing to an individual. It is generally admitted that the country was saved from a general prostration of credit, which must have produced the most fatal consequences, by a sudden and very unprecedented operation of the Bank of England, attended by the most happy results. The lapse of time has enabled the writer to collect the evidences requisite to establish the fact, that the country is indebted to him for originating this important measure, and not to the Bank of England, as has been hitherto supposed. Now although the present House of Commons have set their faces against the public favour being misapplied, confidence is entertained that this will not extend to the denial of justice for services that have been actually performed; and still less to permitting the strong to bear away the eredit which may be due to the weak.

Secondly.-The inquiry may be recommended on economical grounds. Supposing a nobleman had obtained a valuable property by a happy discovery, communicated to him through his solicitors or other agents, whom he continually employed, and whom he paid at a very high rate, which he was desirous to reduce. Now should it be shewn to him by very conclusive evidence that this discovery was not made by his agents, but by a humble labourer on the estate, who would be amply repaid by a comparatively trifling compensation; would it be wise in him to disregard the claim of this poor man, and give to his agents a credit to which they were not entitled ; lieensing them thereby to make charges, which, under the weight of obligation he admitted himself to be under to them, he could not resist? Yet if the IIouse of Commons do not grant this inquiry, they will voluntarily place the country in a similar predicament, and allow the Bank to enjoy a credit, which it is elear from all experience, will somehow or other, be acknowledged to it fifty fold.

Thirdly. - The inquiry is called for on still ligher grounds : namely, that of management. Supposing, to illustrate the case by another allegory, a person was ill of a distemper; that his physician was unable to prescribe a sufficient remedy until he was upon the point of death; and that he was so fortunate at this extremity as suddenly to restore him to perfect health by a very novel and suc- 
cessful course of treatment, applied in his case for the first time. It would be natural for him under these circumstances, to be very grateful to his physician; to think highly of his skill, so happily exerted; to feel greater confidence in him than before; and to resolve the more implicitly to trust to him in future. But supposing it should be shewn as highly probable that he was altogether mistaken, and that the mismanagement of the physician was the true cause of his illness; that his cure was adopted at the suggestion of others, little or no credit being due to the physician for it; he would obviously institute some inquiries to ascertain whether such were the case or not, ere he placed the implicit confidence in him in future, he was disposed to do. Now the nation is precisely in this situation with the Bank of England. It places a most important trust in the lands of the Directors, and it has yet to ascertain whether the history of the panic supplies a proof of their skill, or a proof of their want of it, in the administration of this trust; and consequently, whether it furnishes grounds for increased confidence in them, or reasons for placing some limitation upon the amount hitherto reposed.

Fourthly.-An inquiry is demanded with reference to the principles, which an examination into the origin of the panic, is calculated to develope. It was caused as we have seen, by the Bank contracting its issues three millions and a half in six months, which it was induced to do by the state of the exchanges. It may also be shewn, that one or two heavy pressures in the money market which have subsequently occurred, were produced by similar operations. Now there is reason to believe that these pressures are unnatural ; that they are peculiar to our currency; that they are the result of a defect in it; and that they would not exist under a more correct system. Hence it becomes vitally important, either with reference to the management of the present defective system, by which the evils of it may be mitigated, or with a view to adopting measures for its improvement, that the history of the panic should be inquired into, that persons be examined capable of throwing light upon it, and that the subject be thoroughly investigated.

Fifthly.-An inquiry is equally demanded with reference to the important principle involved in the measure by which the panic was arrested. We have seen, that while it was caused by a contraction of three millions and a half of paper in six months, it was cured by re-issuing twice that amount in as many days, without any evil consequences having resulted from its subsequent withdrawal. We have seen also, that under circumstances similar in principle, though 
not in their details, the Directors had lost sight of those principles by which they were governed, at the memorable period in question; and that there is reason to belicve that their system of management has not been improved by the experience which the panic afforded. It, consequently, is important with reference to the recurrence of such pressures in future, that the principles by which they may be obviated or remedied, should be clearly ascertained by Parliament; and the more especially, as the Direction of the Bank of England is an cver-changing body, and no dependence can, with any safety, be placed upon any system of management by such a body, which is not based on principles well established and generally understood.

Finally.-Inquiry is thus demanded as a matter of justice-it is demanded on the ground of cconomy,-it is demanded with a vicw to ascertain whether the History of the Panic ought to create confidence, or distrust in the managenent of the Bank,-it is demanded with a view to ascertain whether Panics are not the consequence of a defect in our currency,--and it is demanded with a vicw to the development of the principle by which Panics ought to be dealt with in future. There is, however, another reason, which would render such an investigation extremely useful. The present low prices of agricultural produce are attributed, and with almost obvious truth, to a restricted curreney. One of the remedies proposed for this, and generally conceived to be the most effectual, is an alteration of the standard; that is-to coin, three sovercigns, say, into four, or four into five; and by this means diminish the value of the sovereign, and enlarge the currency, by increasing the number in circulation. Our currency being chiefly paper, is, however not capable of this transformation. If the standard were altered, it would have to be met on the part of the Bankers, by a corresponding increase of issucs. Henee, the question arises, might not such an increase be made without such alteration? But so long as we voluntarily shut ourselves out from any thing like an investigation of the principles, upon which our currency dilates and contracts, we shall be perfectly unable to answer this, or any such question. Now while the proposed inquiry, would refer only to one period of its contraction and dilation, and would be limited in its immediate object, to the comparatively unimportant question, of who suggested the measure by which the Panic was arrested; it could not fail, if well conducted, to throw light upon the system generally, and be the means of opening the way to further information, respecting the difficult subject to which the public attention is so strongly called by the situation of the farming interest. 
PUBLISHED BY

JAMES RIDGWAY AND SONS, PICCADILLY,

AND TO BE HAD OF ALL BOOKSELLERS,

\section{A DIGEST OF THE EVIDENCE}

BEFORE THE

\section{SECRET COMMITTEE OF THE HOUSE OF COMMONS, IN 1832,}

\section{ON THE RENEWAL OF THE \\ BANK OF ENGLAND CHARTER;}

ARRANGED, TOGETHER WITH THE TABLES, UNDER PROPER HEADS, WITI STRICTURES, \&c.

BY THOMAS JOPLIN.

1 Vol. 8vo. 14s.

"Thus the Report is not only much abridged, without the omission of any essential fact, but it is reduced to a methodical form, and rendered of easy reference."-Times, March 25.

"The valuable information which it contains is displayed in such a form as renders it doubly useful, because readily available. The Observations are ably written."-Courier.

"The Observations form the most ingenious and original criticism on the course of investigation pursued by the Committee, and the evidence which it drew forth."-Globe.

"We can, however, with great truth, recommend a perusal of this Work, as containing a very clear and able view of the whole bearings of the great question."-Monthly Review. 


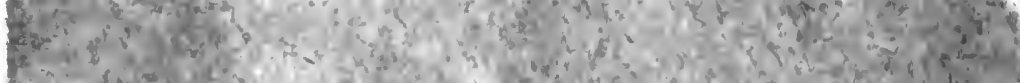

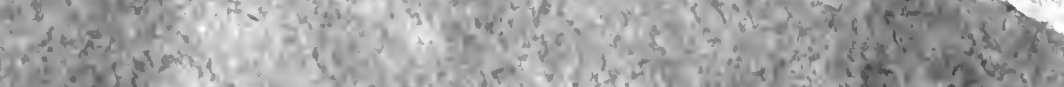
$=20\left\{\begin{array}{l}4 \\ *\end{array}\right.$

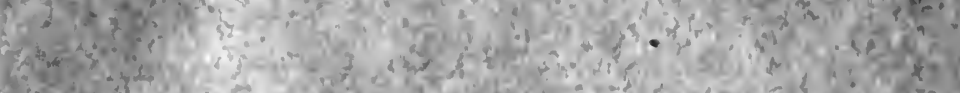

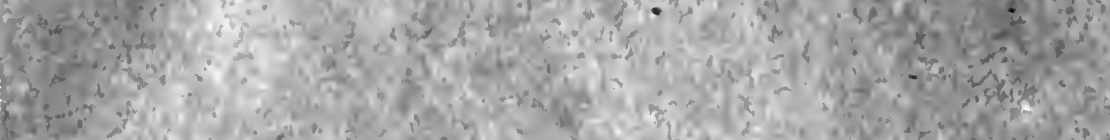

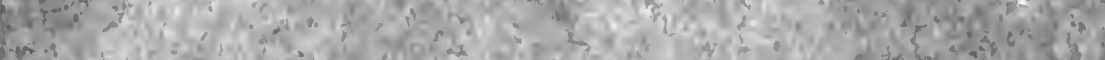

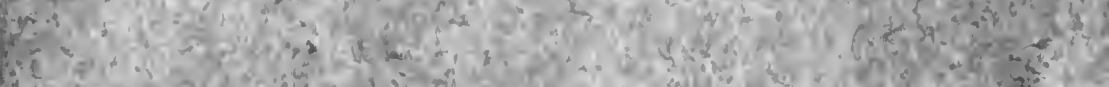

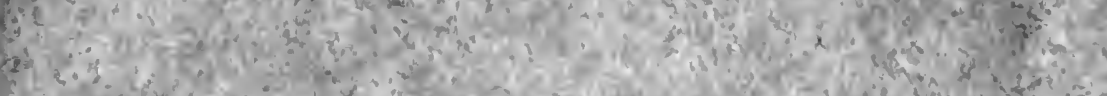
L 23,

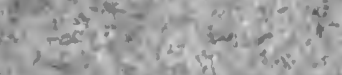

(⿻) I.

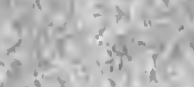

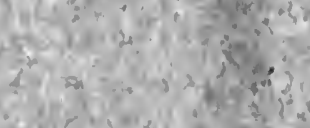

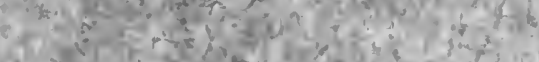

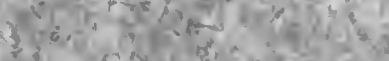
the

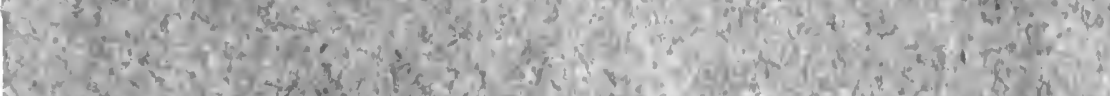

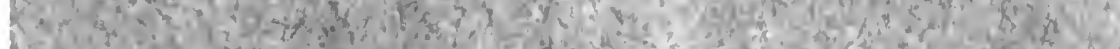

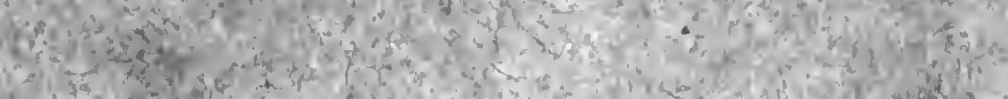

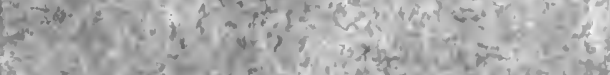

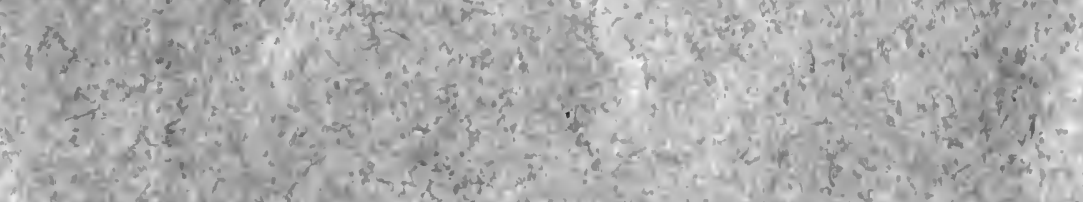
(n)

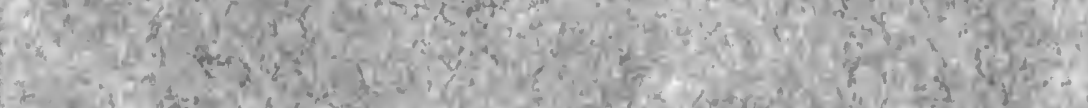

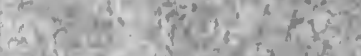

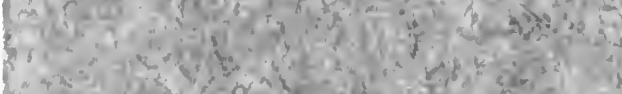

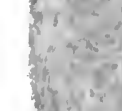

(1)

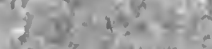

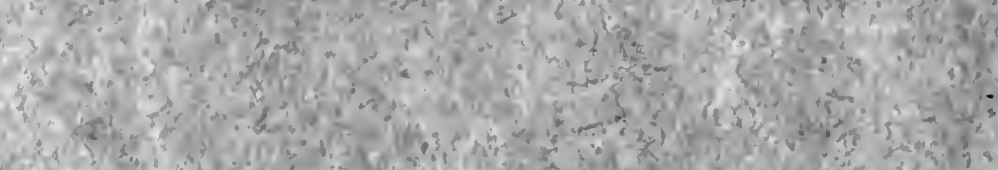

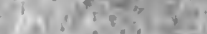

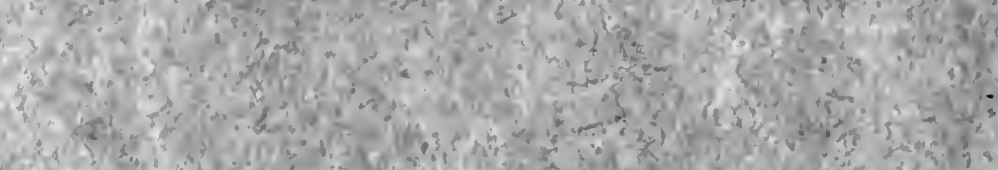

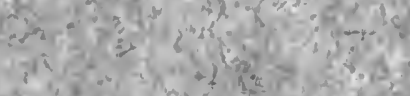

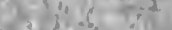

top?

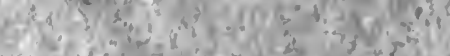

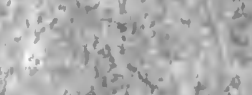

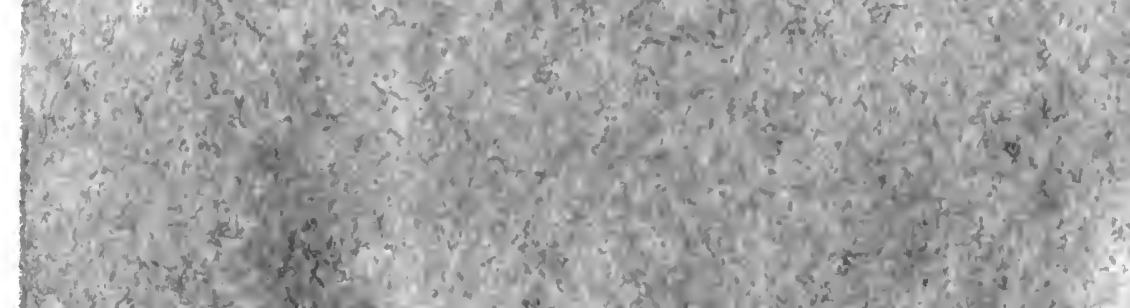

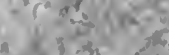
$-618=35$

28 , 



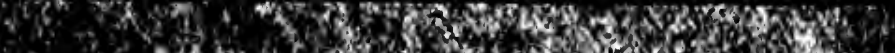

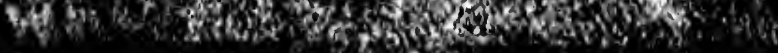

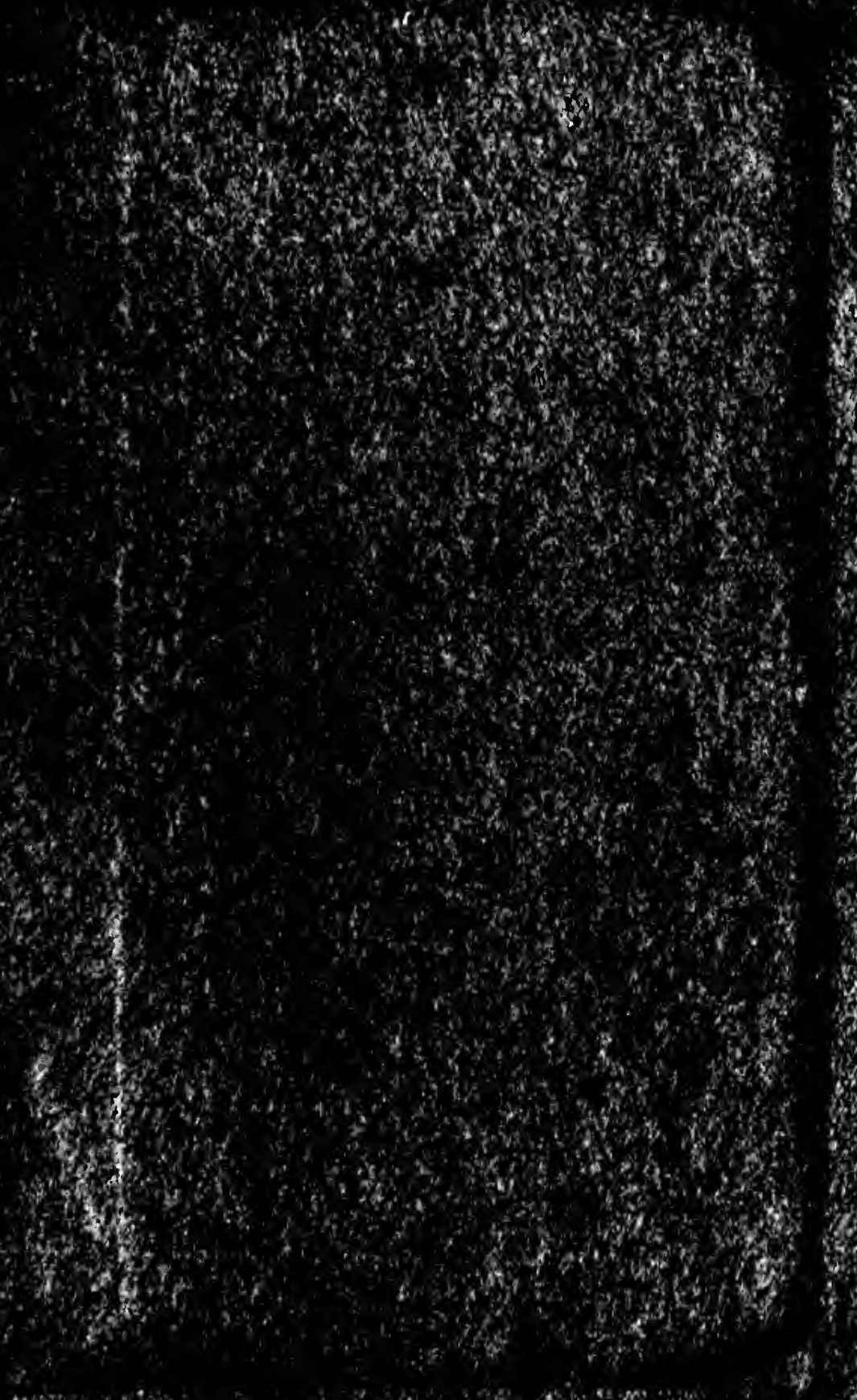

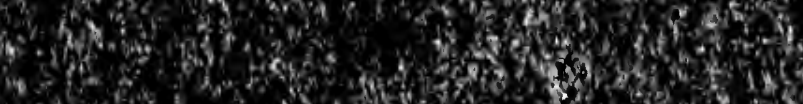

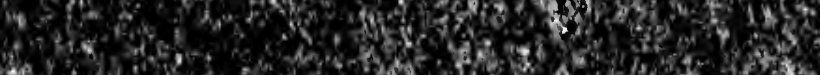

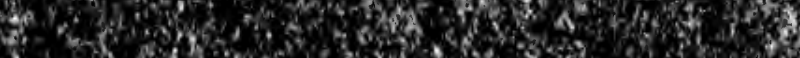

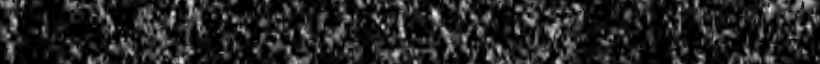

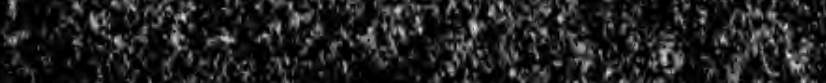

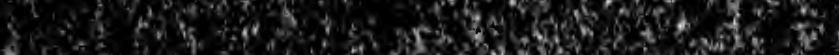
20? 


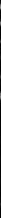

\section{9}

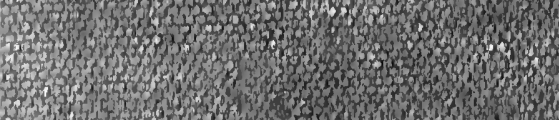

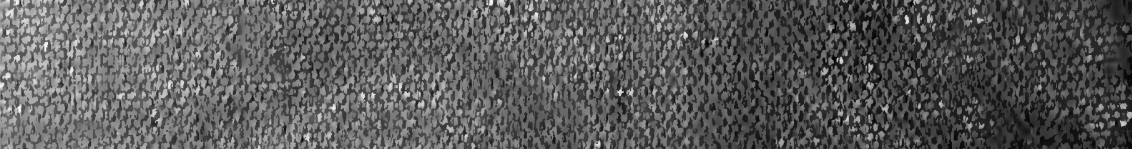

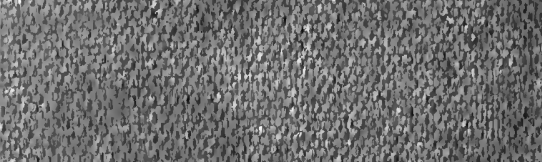

